MICHAŁ IGIELSKI

\title{
Participation \\ of knowledge workers \\ at the implementation of projects in Polish enterprises
}

Ph.D. Michał Igielski Gdynia Maritime University Faculty of Entrepreneurship and Quality Sciensce

\section{Admission}

In functioning of contemporary enterprises the strong emphasis is being put on the implementation of operations unique, called undertakings or projects. The number of folded undertakings about unique character is dominating in enterprises, in which he is turning up for routine action as well as in of these specific projects appointed specially to the accomplishment. Also an outline of functioning of manufacturing companies which in the 20th century they put for the technology, the production and the physical labour is changing. For traditional manufacturing companies exclusively a production of products counted (Gajdzik 2011, p. 35).

We can describe the project the whole of action which let the labour organization in the way driver of the purpose for the achievement established. The organization of projects and teams of projects is becoming a compulsion for the future of the organization. Irrespective of, what look at the project we will choose and from what model we will use the greater attention is being put to the teamwork. Without appropriately of qualified and appropriate employees the enterprise isn't able even to initiate of implementation of 
strategies. Features and capacities to work of the whole of employees constitute most important and most valuable capital of every company however which is often undervalued and lost through the bad labour organization.

New conditioning of functioning of contemporary enterprises (computerization, development of the information network, globalization of the business) paid attention to meaning of the knowledge in enterprises. Employees having a knowledge are becoming a base of the success of enterprises (Perechuda 2005, p. 136). In the 21st century more and more an importance of the role of knowledge workers is emphasizing in the achievement of the goals of the enterprise itself. A new category of specialists, having a useful knowledge for functioning of the enterprise is growing in strength.

Therefore showing the role with which knowledge workers are performing the thanks in Polish enterprises which are raising their market competitiveness the project management is a purpose of the author.

\section{Competitivenesses of businesses in the 21 st century}

Enterprises in Poland, following the example of companies from developed countries of world and integrating with the economy of the European Union, heading also towards the management based on the implementation of projects, must put the strong emphasis on the staff. People for you are often knowledge workers and are helping to keep the excellent communication between individual spheres actions. In this process very much exactly people which are responsible for initiating the innovation have a greater participation and the organization development. They are inventing new products and services, are planning marketing programmes and are creating corporate strategies. They are for the current management of power which is accelerating of economic progress. "If companies are supposed to become more profitable, if strategies are supposed to be a success, if the society is supposed to develop - it will happen this way only, when knowledge workers will perform their work in the more productive and effective way" (Drucker 1997, p. 21).

The success of the enterprise on the market depends on his competitiveness which is a multifaceted phenomenon and therefore differences in his definitions appear. The competitiveness can be determined as the ability to function in market economy conditions. For them greater competitiveness, the position of the enterprise on the market is it more certain, and his functioning and the development aren't exposed to negative extrinsic factors and internal (Nowakowski 2008, p. 345). 
A change of bases of the gained competitive edge in contemporary world is basic conditioning the globalization. An amendment to lines of the production factor is a significant specificity of the current technological progress and of the sale. The not only continuing, but also growing barrier of the demand is settling, that large stores, it capital arranged on the entire world marts, factories, unused powers, raw materials or also semi-finished products. The ones which are able to uncover potential demand, potential products, potential technologies, potential markets, are conditioning very sale, that is the possibility of exploiting production capacities that is potentially the most beneficial places of depositing the production and the sale. They are conditioning to sell, that is completion of main setting the entire economic process. It is possible to describe them as the selected human capital, i.e. the intellectual capital - knowledge workers. This capital in the contemporary manufacturing process is a factor of the minimum, that is relatively rare. Possessing this capital and a skill of caring about his productivity is a base of the long-term competitive edge. The productivity growth of the intellectual capital depends on the ability and the possibility of matching him up with heavy, that is cheap factors arranged on the global market. Globalization leading production factors to the free mobility over border is creating exactly such possibilities. These corporations and these countries which have a factor of the minimum of the manufacturing process at their disposal are made interested in it - with wealth of knowledge [Szymański, 2001, p. 25 - 26].

In the contemporary management of the key mechanism of getting the competitiveness innovating is constant (Kwaśniewska 2012, p. 28). The enterprise of the 21st century must in the centre be taken on the market of innovative actions. He must be a company which is perceived as the forming organization, what is being bound with the response to action of the competition. They must not it to be typically hard effects of action, but the ability to create new ideas, ideas and a new look at known already and existing ideas. For action of this type action perceived as innovations, deciding on the competitiveness of the company is essential. The lack can constitute them - and most often constitutes - threat to her market. Very innovation can assume different shapes and forms. We can also differently perceive her and understand. It is dependent from a field of knowledge, in which he/she is functioning, as well as from the subject of the research and to serve the purpose, for which he has. However always with her initiator, and then with director, there is a man, being an employee of the enterprise (Gomułka 2005, p. 60) 


\section{Definition of the project management}

The contemporary economy is putting the requirement of the structure of competitive edges which are surrendering before entrepreneurs of fast loss of timeliness on account of the activity of rivals. About the win they are becoming determining factors (Wrzosek 2009, pp. 11-12):

- time in meaning of the running speed and the promptness,

- quality,

- price.

A project is an undertaking implemented as part of the determined organization which is an undertaking new, untypical, different from routine action. It is action which the organization never applied. Persons can be involved in a project from the pose of the organization or other organisations. The situation, in which the project is being carried out by one company, is an essential situation considered in this article. Projects can however also be fulfilled by a lot of companies on partnership principles or by private persons (Pawlak 2007, pp. 17-18).

Of project management these are a manner which enabled efficient initiating, drawing up and implementing a project. Such managements functions make it up, as (Wrzosek 2009, p. 19):

- planning,

- organising,

- controlling action,

- motivating directors of the project.

Many definitions of the term of the project management are appearing in world literature. Therefore the author of the article demonstrated characteristics which are dominating in main definitions:

1. American Project Institute Management (website: http: pmi.org, 10.12.2013 date of the access) which is being focussed on issues of managing determined characteristics: managing integration of the project, managing the scope of the project, time management, cost management of project, quality management in the project, personnel management in the project, managing the transport in the project, risk management of the project, managing supplies in the project.

2. H. Kerzner - determined characteristics of the definition of the project most practically, in basing against the person of the project manager, based on his function in the project (Kerzner 1998, p. 4): planning and organising, decision making, being in charge of undertakings in relation to established cells. 
3. J. D. Frame - he concentrated on the need to observe all design assumptions - it isn't interested in the first phases of the life of the project, but observing assumptions made in it (Frame 2001, p. 6.): promptness, budgetary discipline, accomplishing technical requirements. (so-called parameters of the triple restriction - triple constraint).

4. German standards - in this concept the primary focus is located for due determining purposes in the project carried out and to methodology of work (Kousholt 2007, p. 59; Fresk 1984, p. 67): determining purposes from a perspective of the enterprise, the customer, the management and members of a team of designers, harmonization of purposes, comprehensive attempt at the project management (enterprises understood as one of forms of organisation), sense of direction for processes, communication in the team work, integrated model of the methodology of the design and development works.

5. D. Lock-it is the most broad definition, containing all characteristics appearing in other definitions practically. However they are clock very generally (Lock $2003,11-46$ p.): aims of the project, defining the project, organization of the project, dividing up of work, estimating costs, planning with histograms, planning with using the network analysis, planning stores, model using computer programs, authorization of the project, implementing design works, transit and accurate supply, changes, management with progress of works, closing a project.

To sum up, based on cited above characteristics which definitions of the project management are describing, we can state that every of them contains common features, so as (own study):

- target,

- time,

- budget / finances,

- planning / design,

- organising,

- team of projects / people / workers.

Only stalking authors as for the rank and the importance of above issues under the angle of the project management in practice is making them different. How exchanged characteristics are important for every plan best an example will show the bad project management, i.e. construction of a modern bus station in one of the most important cities in Poland in terms of tourist criteria. Although he was recognized too prettiest from our country it is his construction was delayed for 10 months. Additionally he turned out to be too short - at least cells in the project were determined in an optimal way - they didn't think about 
growing tourist movements. Additionally to get commercial surfaces put on the rock bottom, to which they with difficulty were - they were completely not functional. But biggest former problem of costs which at the beginning were planned on the level of the about 5 million PLN. However an amount of the 20 million PLN turned up at the moment of his structure. in order to finish the in total 32 million PLN.

\section{Identification of knowledge workers in enterprises}

Package of the knowledge which the employee is purchasing in the course of the learning process both individual (self-education), as well as collective (trainings, education) lets him gradually become a knowledge worker (Drucker 2006, pp. 13-14). A definition created by T.H. Davenporta (2005, pp. 10,22) is one of the most familiar definitions of the knowledge worker, which he states that for the worker for you the top stair of the know-how, educating or experiencing, but the work performed by them have in requires creating, distribution and using the knowledge. By definition of the one it results that the employee is implementing knowledge in the course of the performance of work what is contributing to the efficiency improvement of the company. The same author recognizes special employees as knowledge workers in the following fields (Davenport 2007, p. 18.):

- management,

- business and financial operations,

- of the computer specialist and mathematical theories,

- architecture and engineering,

- natural sciences and social,

- law,

- medicine and the health care,

- of the service social,

- the education, trainings and the librarianship.

Next knowledge workers - for N. Beck (quoted in: Stewart 2001, p. 59) - these are specialists, senior managers, the maintenance crew staff, scientific, engineers. It seems that pointing at places is an advantage of such classification, where the most knowledge workers are. However nowadays they are these are very large groups and it isn't possible automatically to count everyone to knowledge workers, except for other competition (Kowalski 2011, p. 311). The process of the forming of characteristics of the knowledge worker is constant the man is learning - through the entire life. To essential his guildhall is being done: acquiring the new knowledge still through the process of the constant learning,

Participation of knowledge workers at the implementation of projects in Polish enterprises 
the pragmatism - noticing the possibility of applying the knowledge, the innovative maturity - using the knowledge to new solutions, the self-reliance and the independence of tasks in the realization entrusted or performed functions, mobility - the easiness of the accomplishment of new objectives of various places, teams and undertakings, the professionalism in action - building employee competence on stores of knowledge. Additionally the traditional employee has such features, like loyalty, availability, obedience, correctness, lack of criticism, passive execution of orders. And three basic features of the knowledge worker it: the professionalism, the entrepreneurship and the righteousness. For employees avoiding mistakes was the source of the professional success in traditional organizations, observing formal rules and procedures. In the modern enterprise a commitment, an ingeniousness, a development and a self-improvement belong to such factors (Morawski 2009, p. 26).

To sum up during the synthesis of definitions proposed by researchers of the subject it is possible to state, that (own study):

- is a main purpose of the work of knowledge workers (the work based on the knowledge) creating, distributing or applying the knowledge,

- the thinking is filling for knowledge workers most of the time which are devoting for the work,

- mainly ideas which most often constitute the contribution to the work are a result of the work of knowledge workers other,

- by knowledge workers an expert opinion, experience and the education constitute the base of the performance of work,

- problems which they are untying and chances which knowledge workers are exploiting at their work are most often new, unusual and nonroutine,

- knowledge workers are seeking, are processing and are making up information or data which they are able to take the meaning out and to withdraw on their base necessary actions,

- the work of knowledge workers demands of the innovation, the creativity, the knowledge of solving problems, the system thinking, the greater concentration and focusing one's attention.

Considering the notion and characteristics of the knowledge worker clearly we notice his greater role in modern organizations. To mark he belongs, that the possibility of using them isn't only confining itself to employ best - carrying out of the concept exploiting knowledge workers demands also efficient systems of conversions of recruits. A knowledge worker isn't a position, to which the employee is being employed. It is a position which they are reaching, getting knowledges of solving problems and reaching the highest level of understanding

MICHAŁ IGIELSKI 
the organization, for which they are working. Transforming the entire personnel policy around should so concern the axis a knowledge worker constitutes which both of new, as well as already employed employees. Of employees about the split level of the progress in getting the position of the knowledge worker (Czubasiewicz 2009, pp. 247 - 249).

\section{Role of knowledge workers during the project management in chosen companies}

Literature devoted to managing the team of employees during the implementation of projects, is concentrating on the level of organisation as wholes. With times on the level of teams or the part of the organization (creating and managing a team, the creative teamwork, the organization and tools of the team work, knowledge management in the given department or the function of the company). An interest in the basic component of every organization is small - with correct model of managing a project. Meanwhile the growing soil of the management is giving the possibility of building the competitive edge by achieving the high-efficiency of employees in using with important tools.

Even reaching the most effective level of action possibly isn't guaranteeing the success in the full grade during the project implementation. And so what is still affecting it? The attempt of the generalization of the success to manage in the project is very difficult on account of different of factors, which having an influence on every project component - mainly to every team. It is possible to think, how to the success of all taken action the correct selection of staffs is enjoying considerable influence for the project and exploiting the potential of knowledge workers for that purpose. It alone is regarding the person managing the staff during the project implementation which is of course important (perhaps most important) with cell linking the entire undertaking - with the coordinator, the carer, the adviser and the judge. It is worthwhile giving some thought to his soil, since he is a liaison between the principal of the project and the entire team. A project manager is a leader and a team member. A future of the project depends on his ability, experience and personal features. An author of the article just concentrated on it. He conducted research, in the first half of 2013, in 10 large firms, which acting on ternie of entire country - the examination was conducted as part of the own work of the author of the article. They are reaching their strategic objectives through the project implementation (for the purposes of this study which constitutes only a small proportion of wholes of examinations which they have to be drawn up and discussed in the separate publication, participants 
in the process of the project management were provided with analysis - that is decision-making persons in the company, of project managers and members of a team of project for which two separate questionnaires of questionnaire forms which following types of questions contained were prepared:

- closed off alternative,

- closed off filtering,

- closed off which are exploiting the nominal and order scale,

- determining the rank of the importance of considered subjects,

- half open in the form of conjunction,

- so-called test which let the reply check the frankness respondent,

- test "Self-portrait of Stein" - is used for the identification of needs of respondents and testing the level of expectations,

- of the question to the identification of dehumanizing factors - managements used for determining issues associated with communicating or also a role in the whole process.

In relation to the fact that they are affecting the project management both extrinsic factors as well as internal, specific groups of respondents were established, taking into consideration:

- enterprise in which they are working, that is among others his organizational structure and the size,

- variables of a career, i.e. the position which they are holding, professional experience, work experience, knowledge of the work to the subject performed). Findings were very surprising. A role of special members of a team of designers turned out to be main conditioning the project management (along with their selection to the team). To such specific conditioning, dysfunctions which usually appear, were also associated with it dysfunctions:

- is lacking fundamentals of the recruitment in the recruitment of persons for the project,

- is missing specialists on the labour market,

- is lacking universal standards and tools for the project management in the enterprise,

- is lacking the planned and systematic formation process of truly professional teams of project,

- few professional trainings from the scope of tools and methods of managing a project,

- market heavy costs of above trainings - outside the financial range of design employees and companies, budgets cut down on of project management - low predicted remuneration for the design staff. 
In a similar way to above information, as the crucial success factor of projects carried out, he was shown: competent (and best checked) team of project with the manager as the leader. Directions of necessary changes also accompanied him for the introduction in order to make full use available in the enterprise capital in the figure of knowledge workers:

- of the correct recruitment workers to a team of project, manager too, based on concrete rules,

- additional trainings for employees of teams of project,

- every employee is working only in one project,

- determining the appropriate involvement - roles and respective spheres of competence,

- supporting design employees by the dense management board of business data,

- implementing universal standards and tools for the project management in business data,

- planned and systematic formation process of truly professional teams of project in enterprise data.

All theories and practical analysis are confirming how a human factor is very important in the aspect of the manager of projects and all team members. It is obvious, that the success of a project manager isn't being measured only through the result of the project (product), the duration or the amount of budget, but also by the achieved more late effect, opinions of the principal and partners. We must have adequate tools at our disposal in order to:

- to assess, whether participation of the those responsible too of team is rational and optimum in the project,

- to streamline and to design tools of due managing the group - are often these are strange people,

- to examine causes and conditions of the commitment of employees into the project implementation.

\section{Summary}

It is possible to meet knowledge workers almost in all organizations of activity in developed economies, irrespective of the kind conducted. What per cent it is hard exactly to describe employees with the whole knowledge workers are deciding, since on the global level we don't have at our disposal one, with universal definition (Davenport 2005, p. 5-6).

Being guided by deliberations T. H. Davenporta (2005) and with specific analysis of studied cases, boldly it is possible to state that we will meet knowledge 
workers also in organizations operating based on the project management. We will meet them amongst positions requiring the creativity, the custom thinking and the innovation and amongst persons which they are occupying of a position of managers or project coordinators.

Unfortunately a way of finding employees which are knowledge workers is a main problem or aren't. This issue is stirring up controversy a lot, because since they are supposed to decide about the competitive edge of enterprises in the contemporary economy, correct identifying their personal features and idiosyncrasies of their work is necessary (of the work based on the knowledge).

Unfortunately in Polish reality we are coming across barriers, hampering the optimal use of the potential of employees from the business progress to which they belong above all:

- members of teams of project, are being employed haphazardly,

- on the labour market is sorting special brains trust from the scope project management,

- in enterprises is sorting developed mechanisms for the implementation of projects - there are no design structures,

- in enterprises planned and systematic formation processes of permanent teams of project and deepening the knowledge of employees participating in them are missing,

- participants in projects don't have a knowledge being enough about their realization, aren't also being trained in this respect

- employees aren't aspiring to increasing their knowledge, because are being employed only for the purposes of the project given to the realization, for the low low remuneration for many duties.

To sum up in order better to exploit the potential of employees, in it of knowledge workers, during the implementation of projects, according to the author's of the article, belongs above all:

- to implement fundamentals of principles of the recruitment workers for projects

- to implement to the market of the offer educational for wanting persons to carry out a project - to prepare specialist trainings and courses for employees of enterprises carrying out a project,

- to accustom to and to popularize standards and tools for the project management in enterprises,

- to create design budgets according to standards being in force on the market remuneration for the staff appropriate to performed tasks and liabilities. 


\section{Summary}

Participation of knowledge workers at the implementation of projects in Polish enterprises

For countries of contemporary world which are functional in the global economy, more and more a vision of carrying existing economic assumptions on based on assumptions associated with current functioning is becoming fleeting. Accessing the sustainable development to the route by creating more flexible organizational structures to market hesitations, in the support can turn out to be getting out of such an impasse for many enterprises about high special human capital. Enterprises should aspire to the economy based on the knowledge. Hierarchical organizations about the slender structure are being replaced by sentence structures based on teams of project. This phenomenon is increasing meaning of the specific group of employees which are becoming knowledge workers and in building the competitive position enterprises are acting the greater role. He appears needs for the change of behaviours of employers in the attitude to employees, since depends on them more and more - their knowledge is valuable capital for the company. We must create such conditions for them can share the knowledge for them and all the time form it for the good of the company.

Keywords: project, project management, a project manager, a team of project, the knowledge worker.

\section{Streszczenie}

Udział pracowników wiedzy przy realizacji projektów w polskich przedsiębiorstwach

Dla krajów współczesnego świata, funkcjonujących w gospodarce globalnej, coraz bardziej ulotna staje się wizja kontynuowania dotychczasowych założeń gospodarczych w oparciu o założenia związane $\mathrm{z}$ dotychczasowym funkcjonowaniem. Wyjściem z takiego impasu może okazać się dla wielu przedsiębiorstw wejście na drogę trwałego rozwoju poprzez tworzenie struktur organizacyjnych bardziej elastycznych na wahania rynkowe, w oparciu o wysoko wyspecjalizowany kapitał ludzki. Przedsiębiorstwa powinny dążyć zatem do gospodarki opartej 
na wiedzy. Hierarchiczne organizacje o wysmukłej strukturze są zastępowane przez struktury zadaniowe oparte na zespołach projektowych, co zwiększa znaczenie konkretnej grupy pracowników, którzy stają się także stopniowo pracownikami wiedzy i odgrywają co raz ważniejszą rolę $\mathrm{w}$ budowaniu pozycji konkurencyjnej przedsiębiorstwa. Prowadzi to także do konieczności zmiany zachowań pracodawców w stosunku do pracowników, gdyż od nich zależy coraz więcej - ich wiedza to cenny kapitał dla firmy. Trzeba zatem stworzyć im takie warunki, by mogli z jednej strony wiedzą się dzielić, a z drugiej dążyć do tworzenie nowej wiedzy użytecznej dla firmy.

\section{Słowa}

kluczowe: projekt, zarządzanie projektami, kierownik projektu, zespół projektowy, pracownik wiedzy.

\section{References}

1. Czubasiewicz H. (2009), Pracownicy wiedzy jako wyzwanie dla zarzadzania zasobami ludzkimi, in: A. Potocki (ed.), Globalizacja a społeczne aspekty przeobrażeń i zmian organizacyjnych, Difin, Warszawa.

2. Davenport T. H. (2005), Thinking for a Living. How to get better performance and results from knowledge workers, Harvard Business School Press, BostonMassachusetts.

3. Davenport T.H. (2007), Zarzadzanie pracownikami wiedzy, Wolters Kluwer, Kraków.

4. Drucker F. P. (2006), Menedżer skuteczny, Nowoczesność, Warszawa.

5. Drucker P.F. (1999), Społeczeństwo pokapitalistyczne, PWE, Warszawa.

6. Drucker P.F. (1997), The future that has already happened, "Harvard Business Review", September-October.

7. Gajdzik B. (2011), Cechy, miejsce i rola pracownikawiedzyw systemie zarządzania bezpieczeństwem $i$ higiena pracy przedsiębiorstwa produkcyjnego, Zeszyty naukowe Wyższej Szkoły Zarządzania Ochroną Pracy w Katowicach, Nr 1(7)/2011, Katowice.

8. Gomułka S. (2005), Innowacje i trwałość wzrostu polskiej gospodarki, Warszawa.

9. Frame J.D. (2001), Zarzadzanie projektami w organizacjach, WIG - Press, Warszawa.

10. Fresk E. (1984), Grundlagen der Organisations, Verlag Gabler, Wiesbaden. 
11. Kerzner H. (1998), Project Management. A System Approach to P1annitg, John Wiley \& Sons, Inc., New York.

12. Kowalski T. (2011), Pojęcie i cechy pracownika wiedzy, "Studia Lubuskie", Tom VII, PWSZ, Sulechów.

13. Kousholt B. (2007), Project Management - teoria i praktyka, PWN, Warszawa.

14. Kwaśniewska A. (2012), Sukces przedsiębiorstwa oparty na wiedzy, „Think”, WSIiZ, Rzeszów.

15. Lock D. (2003), Podstawy zarządzanie projektami, PWE, Warszawa.

16. Morawski M. (2009), Zarzadzanie profesjonalistami, PWE, Warszawa.

17. Nowakowski M. (2008), Eurobiznes, SGH, Warszawa.

18. Pawlak M. (2007), Zarzadzanie projektami, PWN, Warszawa.

19. Perechuda K. (2005), Zarządzanie wiedza w przedsiębiorstwie, PWN, Warszawa.

20. Stewart T.A. (2001), The Wealth of Knowledge. Intellectual Capital and the Twenty-First Century Organization, Nicholas Brealey Publishing, London.

21. Strona Internetowa: http:// pmi.org// (10.12.2013 - data dostępu).

22. Szymański W. (2001), Globalizacja - wyzwania i zagrożenie, Difin, Warszawa.

23. Wrzosek K (2009), Wprowadzenie do zarządzania projektami, w: J. Skalik (ed.), Zarządzanie projektami, UE, Wrocław. 